\title{
MODEL PEMBELAJARAN INTERAKTIF KELOMPOK PADA MATA PELAJARAN SENI TARI
}

\author{
Hilma Mitalia Shalihat \\ Universitas Sari Mutiara \\ hilmamithalia@gmail.com
}

\begin{abstract}
Abstrak
Model pembelajaran interaktif adalah kegiatan guru secara terprogram dalam desain instruksional, untuk membuat siswa belajar aktif, yang menekankan pada penyediaan sumber belajar. Penelitian ini bertujuan untuk mendeskripsikan dan mengetahui: (1) Pelaksanaan pembelajaran seni tari di SMP Bina Sejahtera, (2) Faktor penghambat dan pendukung yang dihadapi dalam model pembelajaran Interaktif Kelompok pada Mata Pelajaran Seni Tari di Bina Sejahtera. Penelitian ini menggunakan penelitian kualitatif, dengan fokus penelitian pelaksanaan model pembelajaran Interaktif Kelompok pada mata pelajaran seni tari di Bina Sejahtera. Teknik pengumpulan data menggunakan observasi, wawancara dan dokumentasi. Teknik analisis data dengan cara mereduksi, penyajian data dan menyimpulkan semua informasi secara benar. Hasil penelitian menunjukkan bahwa pembelajaran tari dimulai dengan pendahuluan, kegiatan inti dan penutup. Hasil pembelajaran dapat dilihat dari segi kognitif, afektif, dan psikomotorik. Pembelajaran Interaktif kelompok mempunyai faktor penghambat dan pendukung. Saran dalam penelitian ini yaitu motivasi siswa dalam pembelajaran Seni Tari lebih ditingkatkan supaya siswa putra tidak ada lagi yang beranggapakan menari hanya untuk siswa putri, dan pembelajarn lainnya di Bina Sejahtera sebaiknya menggunakan model pembelajaran interaktif kelompok.
\end{abstract}

Keyword : Pembelajaran, Interaktif, Seni Tari, SMP Bina Sejahtera.

\section{PENDAHULUAN}

Model Pembelajaran Interaktif merupakan salah satu model pembelajaran yang sangat penting untuk meningkatkan kemampuan akademik siswa. Materi ajar dipilih dan disusun menjadi paket pro dan kontra. Siswa dibagi ke dalam beberapa kelompok dan setiap kelompok terdiri dari empat orang. Di dalam kelompoknya, siswa (dua orang mengambil posisi pro dan dua orang lainnya dalam posisi kontra) melakukan perdebatan tentang topik yang ditugaskan. Laporan masing-masing kelompok yang menyangkut

Jurnal Insitusi Politeknik Ganesha Medan 
kedua posisi pro dan kontra diberikan kepada guru. Selanjutnya guru dapat mengevaluasi setiap siswa tentang penguasaan materi yang meliputi kedua posisi tersebut dan mengevaluasi seberapa efektif siswa terlibat dalam prosedur debat, kemudian guru meluruskan masalah yang menjadi perdebatan (Rahman 2011: 2)

II.

Kenyataannya dengan adanya guru yang berkompeten dibidangnya, masih banyak siswa yang nilainya dibawah Kriteria Ketuntasan Minimal (KKM) yaitu KKM yang ditetapkan SMP Bina Sejahtera, konsentrasi siswa dalam pembelajaran Seni Tari kurang, kurangnya sikap menghargai guru dalam pelajaran Seni Tari, dan motivasi siswa dalam pembelajaran Seni Tari kurang. Ini menjadi alasan mengapa peneliti melakukan penelitian di SMP Bina Sejahtera.

\section{LITERATURE REVIEW}

Pembelajaran mempunyai tujuan yang sangat penting yaitu untuk mengubah sikap, mengubah ketrampilan, menambah pengetahuan dalam berbagai bidang ilmu (Dalyono 2007: 50). Pembelajaran juga dapat diartikan sebagai suatu proses interaksi antara peserta didik (siswa) dengan lingkungannya, sehingga terjadi perubahan perilaku ke arah yang lebih baik (Mulyasa, 2006:156). Pembelajaran terdapat Komponen-komponen pembelajaran ditinjau dari pendekatan sistem, maka dalam prosesnya suatu pembelajaran akan melibatkan berbagai komponen, diantaranya: tujuan, guru, peserta didik, materi, metode, media serta evaluasi (Surakhmad 1980: 16).

Tari adalah gerak seluruh tubuh disertai bunyian (gamelan) diatur menurut irama lagunya, gending, ekspresi muka, disertai dengan isi dan makna tarinya (Jazuli 2001: 45). Tari mempunyai arti penting dalam kehidupan manusia karena dapat memberikan berbagai manfaat, seperti hiburan dan sarana komunikasi. Tari merupakan alat ekspresi ataupun sarana komunikasi seorang seniman kepada orang lain (penonton/penikmat) (Jazuli 1994: 1). Tari adalah ekspresi perasaan tentang sesuatu lewat gerak ritmis yang indah yang telah mengalami stilisasi dan distors (Jazuli 1994: 82).

Pembelajaran interaktif menurut Damyati dan Mudjiono (1999: 27) adalah kegiatan guru secara terprogram dalam desain instruksional, untuk membuat siswa belajar aktif, yang menekankan pada penyediaan sumber belajar. Pembelajaran Interaktif Kelompok dapat mengklasifikasi dan menafsirkan ide-ide, menguji berdasarkan persepsi orang lain dan pemahaman menurut tradisi, dan mengaplikasikannya pada situasi aktual. Kelompok mencari jawaban terhadap permasalahan yang timbul, melakukan penelitian maupun laporan, mendiskusikan permasalahan, dan mengevaluasi hasil-hasil yang telah dicapai maupun proses yang dijalankan (Sumiyatiningsih 2006: 82-83). Tahapan dalam model pembelajaran interaktif menurut Faire dan Cosgrove dalam Harlen (1996: 28) terdiri dari persiapan pengetahuan awal, kegiatan eksplorasi, pertanyaan siswa, penyelidikan, 
pengetahuan akhir dan refleksi. Kelebihan dari model pembelajara interaktif yang dinyatakan Nurhasanah, (2004: 17) diantaranya: Siswa lebih banyak kesempatan untuk melibatkan keingintahuannya pada objek yang akan dipelajari, Melatih siswa mengungkapkan rasa ingin tahu melalui pertanyaan-pertanyaan yang diajukan siswa mupun guru, Memberikan sarana bermain bagi siswa melalui kegiatan eksplorasi dan investigasi, Guru sebagai fasilitator, motivator, dan perancang aktivitas belajar, Hasil belajar akan lebih bermakna.

\section{RESEARCH QUESTIONS}

Permasalahan yang akan dikaji yaitu:

1) Bagaimana pelaksanaan model pembelajaran interaktif kelompok terhadap pembelajaran seni tari di SMP Bina Sejahtera,

2) Apa saja faktor penghambat dan pendukung dalam pembelajan interaktif kelompok terhadap pembelajaran seni tari di SMP Bina Sejahtera.

\section{METHOD}

Penelitian ini menggunakan pendekatan deskriptif kualitatif. Sasaran utama penelitian ini adalah pembelajaran seni tari yang menggunakan model pembelajaran interaktif kelompok di SMP Bina Sejahtera. Untuk memperoleh data yang diperlukan dalam penelitian ini, cara yang dilakukan adalah melakukan observasi, wawancara dan dokumentasi. Analisis data yang digunakan dalam penelitian ini mengacu pada analisis Rohidi (1992:15) terdiri dari tiga tahap, antara lain reduksi data, penyajian data, dan menarik kesimpulan / verifikasi.

\section{DISCUSSION}

\section{Pelaksanaan Model Pembelajaran Interaktif Pada Mata Pelajaran Seni Tari di SMP Bina Sejahtera}

Pembelajaran seni tari di SMP Bina Sejahtera dilaksanakan pada masing-masing kelas satu kali dalam satu minggu. Pelaksanaan pembelajaran seni tari setiap kelas dibuat menjadi 4 kelompok, setiap kelompok terdiri atas 6 sampai 7 siswa. Hari Senin adalah pembelajaran seni tari untuk kelas VII E dan VII A, hari Selasa kelas VII D, hari Rabu kelas VII C, hari Kamis kelas VII F dan VII B. Pembelajaran seni tari dilaksanakan selama $2 \times 40$ menit atau dua jam pelajaran pada masing-masing kelas. Pembelajaran yang dilaksanakan ditempuh melalui tiga tahapan yaitu pendahuluan, kegiatan inti, dan penutup. Hasil pembelajaran seni tari di SMP Bina Sejahtera menggunakan model pembelajaran intteraktif kelompok terlihat dari segi kognitif, afektif, dan psikomotorik.

Jurnal Insitusi Politeknik Ganesha Medan

Juripol, Volume 4 Nomor 1 Maret 2021 


\section{Pelajaran Seni Tari Kelas VII E Tanggal 6 Febuari 2012}

Pembelajaran Seni Tari pada kelas VII E terdiri dari tiga tahapan yaitu pendahuluan, kegitan inti dan penutup. Pendahuluan yaitu Ibu Wahyu memberikan apersepsi kepada siswa tentang materi yang akan diajarkan yaitu siswa mengeksplorasi gerak tari secara berkelompok.

Kegiatan Inti yaitu siswa melakukan kegiatan apresiasi, menonton video tari Gundul Pacul, Ibu Wahyu menyuruh siswa untuk berkelompok dan berdiskusi mengeksplorasi geraak tari Gundul Pacul. Kegiatan diskusi selesai, Ibu Wahyu memanggil kelompok 1 untuk menampilkan hasil diskusinya. Ibu Wahyu memberikan evaluasi kepada kelompok 1. Ibu Wahyu memanggil aggota kelompok 1 yaitu Rina dan Nita untuk menari bersama-sama, dilannjutkan dengan Ibu Wahyu memberberikan evaluasi dari gerakan yang ditampilkan Rina dan Nita. Hasil pembelajaran kelas VII E dapat dilihat dari segi kognitif, afektif dan psikomotorik. Kognitif yaitu seperti yang dikatakan oleh Rina (Wawancara 6 Febuari 2012) bahwa Rina sudah agak bisa mengerti cara mengeksplorasi gerak tari. Afektif yaitu seperti yang dikatakan Rina bahwa, Rina merasa malu dan takut ditertawakan oleh temannya. Psikomotor yaitu Siswa kelas VII E dapat mengeksplorasi gerak tari tari Gundul Pacul.

Penutup yaitu Ibu Wahyu memberikan kesimpulan dari pembelajaran hari ini dan memberikan tugas. Kesimpulannya yaitu usaha kalian dalam membuat ide-ide gerak tari siswa bagus, pembelajaran kali ini didapatkan kerja sama, keberanian menuangkan ide, saling menghargai. Tugasnya yaitu siswa berlatih secara berkelompok lagi di rumah dan minggu depan menarinya sudah menggunakan musik.

\section{Pelajaran Seni Tari Kelas VII A Tanggal 6 Febuari 2012}

Pembelajaran Seni Tari pada kelas VII A terdiri dari tiga ttahapan yaitu pendahuluan, inti dan penutup. Pendahuluan yaitu Ibu Wahyu memberikan apersepsi yaitu siswa berkelompok kemudian berdiskusi mengeksplorasi gerak tari Gundul Pacul.

Kegiatan Inti yaitu Ibu Wahyu memutarkaan video Gundul Pacul sebagai kegiatan apresiasi, dilanjutkan dengan Ibu Wahyu menjelaskan tentang tari Gundul Pacul dan siswa yang bertanya kepada Ibu Wahyu yaitu Ami bertanya tentang arti gembelengan. Tanya jawab selesai, Ibu Wahyu memberikan waktu 25 menit, untuk mengeksplorasi gerak tari Gundul Pacul secara kelompok. Ibu Wahyu memanggil kelompok 4 untuk menamplkan hasil diskusinya, dilanjutkan dengan Ibu Wahyu memberikan evaluasi. Hasil pembelajaran kelas VII A dapat terlihat dari segi kognitif, afektif, dan psikomotorik. Kognitif yaitu siswa bernama Ami berani bertanya kepada guru tentang arti gembelengan. Afektif yaitu ada salah satu kelompok berdiskusi yang salah satu anggotanya berjalan-jalan sendiri seperti yang terlihat pada gambar 4.13. Psikomotorik yaitu siswa dapat mengeksplorasi gerak tari Gundul Pacul secara berkelompok.

Jurnal Insitusi Politeknik Ganesha Medan 
Penutup yaitu Ibu Wahyu mengevaluasi gerak tari yang para siswa tampilkan dan memberikan tugas kepada siswa. Evaluasinya yaitu siswa cenderung masih meniru gerakan video, dan perhatian sikap saat menari seperti sikap tangan, kepala dan kaki. Tugas yang diberikan Ibu Wahyu yaitu minggu depan maju secara berkelompok, gerakan harus sudah hafal dan minggu depan sudah menggunakan musik.

\section{Pelajaran Seni Tari Kelas VII D tanggal 7 Febuari 2012}

Pembelajaran Seni Tari di kelas VII C terdiri dari tiga tahapan yaitu pendahuluan, kegiatan inti, dan penutup. Pendahuluan yaitu Ibu Wahyu memberikan pree test tentang tari Jaranan dan siswa berama Ali yang bisa menjawab pertanyaan dari Ibu Wahyu. Ibu Wahyu juga menjelaskan tentang tari Jaranan dan materi pembelajaran yang akan dipelajari.

Kegiatan inti yaitu apresiasi, siswa menonton video tari Jaranan, dilanjutkan dengan Ibu Wahyu menyuruh siswa untuk membentuk kelompok dan berdiskusi tentang mengeksplorasi gerak tari Jaranan. Siswa diberikan waktu 25 menit untuk berdiskusi. Kegiatan diskusi selesai, Ibu Wahyyu memanggil kelompok 1 untuk menampilkan hasil diskusinya. Kelompok 1 selesai, Ibu Wahyu memberikan evaluasi. Hasil pembelajaran di kelas dapat dilihat dari segi kognitif, afektif dan psikomotorik. Kognitif yaitu siswa mampu memahami tentang tari Jaranan. Afektif yaitu semua siswa terlihat aktif dalam pembelajaran Seni Tari. Psikomotorik yaitu siswa mampu mendemonstrasikan tentang tari Jaranan.

Penutup yaitu Ibu Wahyu menyimpulkan hasil mengeksplorasi gerak tari Jaranan secara kelompok dan tugas kepada siswa. Evaluasi yang diberikan oleh Ibu Wahyu yaitu semua kelompok terlihat kurang kompak, tenaga yang digunakan kurang maksimal. Tugas yang diberikan Ibu Wahyu kepada siswa yaitu minggu depan harus sudah terlihat kompak dan tenaganya harus ditambah, minggu depan juga sudah mulai menggunakan musik.

\section{Pelajaran Seni Tari Kelas VII C tanggal 8 Febuari 2012}

Pembelajaran Seni Tari kela VII C terdiri dari tiga tahapan yaitu pendahuluan, kegiatan inti, dan penutup. Pendahuluan yaitu Ibu Wahyu memberikan apersepsi yaitu siswa mengeksplorasi gerak tari Gundul Pacul secara berkelompok yyag kelompoknya terdiri dari 6 sampai 7 siswa.

Kegiatan Inti yaitu apresiasi, siswa menoton video tari Gundul Pacul, dilanjutkan dengan siswa secara berkelompok mengeksplorasi gerak tari Gundul Pacul, dan Ibu Wahyu memberikan waktu 25 menit untuk berdiskusi tentang mengeksplorasi gerak tari. Kegiatan diskusi selesai, Ibu Wahyu menawarkan kepada siswa untuk menampilkan haasil diskusinya. Semua siswa megangkatkan tangannya, Ibu Wahyu menunjuk kelompok 2 
karena kelompok 2 yang mengangkatkan tangannya terlebih dahulu. Kelompok 2 menampilkan hsil mengeksplorasi gerak tari, dilanjutkan dengan Ibu Wahtu memberikan evaluasi. Hasil pembelajaran kelas VII C dapat dilihat dari segi Kognitif, Afektif dan Psikomotorik. Kognitif yaitu siswa sangat kreatif karena memadukan gerakan tari dengan gerakan permainan. Afektif yaitu siswa merasa percaya diri saat menampilkan hasil eksplorasi. Psikomotoriknya yaitu siswa dapat menampilkan hasil eksplorasi gerak tari Gundul Pacul di depan kelas secara berkelompok.

Penutup yaitu Ibu Wahyu memberikan kesimpulan dan mengevaluasi tentang pembelajaran kali ini, yaitu mengembangkan gerakan tari tidak harus selamanya sama persis dengan video yang dilihat dan minggu depan sudah menggunakan musik, dan harus berlatih dirumah dengan kelompoknya.

\section{Pelajaran Seni Tari Kelas VII F tanggal 9 Febuari 2012}

Tanggal 9 Febuari yaitu pembelajaran Seni Tari kelas VII F. Pembelajaran Seni Tari terdiri dari pendahuluan, kegiatan inti, dan penutup. Pendahuluan yaitu Ibu Wahyu memberikan apersepsi tentang tari Lir Ilir, yaitu tari Lir ilir merupakan tarian yang berasal dari daerah Jawa Tengah, Arti tari Lir Ilir yaitu kehidupan yang dituangkan dalam bentuk syair yang indah.

Kegiatan Inti yaitu apresiasi, siswa mnonton video tari Lir Ilir dilanjutkan dengan Ibu Wahyu menjelaskan materi pembelajaran. Materi pembelajaran yaitu siswa membentuk kelompok, 1 kelas dibagi menjadi empat kelompok. Tugas siswa yaitu mengekplorasi gerak tari Lir Ilir secara berkelompok, dan diberikan waktu 25 menit. Kegiatan diskusi berlangsung, siswa bernama Rayi bertanya kepada Ibu Wahyu tentang mengeksplorasi gerak tari. Kegiatan diskusi selesai, Ibu Wahyu memanggil kelompok 3 untuk menampilkan hasil mengeksplorasi gerak tari, kelompok 3 belum siap. Ibu Wahyu memanggil kelompok 1, 2, dan 4 semua belum juga belum siap. Hasil pembelajaran Seni Tari kelas VII F terlihat dari segi Kognitif, Afektif dan Psikomotorik. Kognitif yaitu siswa kurang begitu memahami cara mengeksplorasi gerak tari. Afektif yaitu siswa kurang aktif karena banyak siswa yang hanya diam saat berdiskusi. Psikomotorik yaitu siswa tidak mampu memeragakan hasil mengeksplorasi gerak tari Lir Ilir.

Penutup yaitu Ibu Wahyu mengevaluasi dan memberikan tugas kepada siswa. Evaluasinya yaitu pembelajaran kurang efektif karena siswa ribut sendiri. Tugasnya yaitu siswa harus sudah siap maju perkelompok dan minggu depan sudah menggunakan musik.

\section{Pelajaran Seni Tari Kelas VII B tanggal 9 Febuari 2012}

Pembelajaran Seni Tari di kelas VII B terdiri dari 3 tahapan yaitu pendahuluan, kegiatan inti, dan penutup. Pendahuluan yaitu Ibu Wahyu memberikan apersepsi kepada 
siswa, pembelajaran kali ini mengeksplorasi gerak tari Padang Bulan secara kelompok. Kelomponya 1 kelas dibagi menjadi 4 kelompok.

Kegiatan inti yaitu kegiatan apresiasi yaitu Ibu Wahyu memutarkan video Padang Bulan, dilanjutkan dengan siswa berdiskusi dengan kelompoknya untuk mengeksplorasi gerak tari Padang Bulan selama 25 menit. Kegiatan diskusi selesai, Ibu Wahyu memanggil kelompok 2 untuk menampilkan hasil dikusinya. Kelompok 2 selesai menampilkan hasil diskusinya, Ibu Wahyu memanggil Nia yang merupakan anggota dari kelompok 2 untuk memeragakan kembali hasil diskusi kelompoknya sendiri. Nia selesai memeragakan, Ibu Wahyu memberikan kesempatan kepada siswa untuk memberikan komentar dari gerakan yang Nia peragakan. Niken dan Siti memberikan komentarnya. Hasil pembelajaran Seni Tari kelas VII B, dapat dilihat dari segi kognitif, afektif dan psikomotorik. Kognitif yaitu siswa mampu memahami tentang tari Padang Bulan. Afektif yaitu siswa saling beradu argumen saat mengeksplorasi gerak tari Padang Bulan di kelompoknya masing-masing. Psikomotorik yaitu siswa mampu memeragakan hasil mengeksplorasi gerak tari Padang Bulan secara kelompok.

Penutup yaitu Ibu Wahyu memberikan evaluasi pada pembelajaran kali ini dan tugas kepada siswa. Evaluasinya yaitu semua siswa gerakan dalam kelompoknya masingmasing kurang kompak, teknik geraknya, harus memperhatikan sikap tangan, sikap kaki, sikap kepala yang benar, power geraknya ditambah. Tugasnya yaitu menampilkan hasil mengeksplorasi kelompok kalian harus sudah menggunakan musik

\section{Pelajaran Seni Tari Kelas VII E tanggal 5 Maret 2012}

Pembelajaran Seni Tari kelas VII E terdiri dari tiga tahapan yaitu pendahuluan, kegiatan inti, dan penutup. Pendahuluan yaitu Ibu Wahyu memberikan apersepsi yaitu pembelajaran kali ini akan mengevaluasi gerak tari dari hasil diskusi. Kegiatan Inti yaitu siswa berlatih dengan kelompoknya masing-masing selama 15 menit. Siswa selesai berlatih dengan kelompoknya masing-masing, Ibu Wahyu memanggil kelompok 1 dan 2 untuk menampilkan hasil mngeksplorasi gerak tari kelompoknya. Kelompok 1 dan 2 menampilkan hasil mengeksplorasi gerak tari, diilanjutkan dengan bu Wahyu mengevaluasi gerakannya. Ibu Wahyu memanggil perwakilan kelompok 1 dan 2 untuk meenampilkan kembali. Kelompok 1 diwakilkan oleh Arizal dan kelompok 2 Eko. Arizal dan Eko menari bersama-sama, tetapi dengan gerakan hasil diskusi kelompok masingmasing. Arizal dan Eko selesai memeragakan, Ibu Wahyu meminta salah satu siswa untuk memberikan komentar dari gerakan Eko dan Arizal. Siswa bernama Hani memberikan komentarnya, yaitu Eko dan Arizal kurang percaya diri dalam menari, terus Eko dan Arizal tertawa terus. Hasil pembelajaran Seni Tari kelas VII E dapat dilihat dari segi kognitif, afektif, dan psikomotorik. Kognitif yaitu siswa mampu mengeksplorasi gerak tari secara kelompok. Afektif yaitu siswa merasa kurang percaya diri harus menari di hadapan teman-

Jurnal Insitusi Politeknik Ganesha Medan 
temannya. Psikomotorik yaitu siswa mampu memeragakan hasil mengeksplorasi gerak tari secara kelompok.

Penutup yaitu Ibu Wahyu mngevaluasi dan memberikan tugas kepada siswa. Evaluasinya yaitu semua siswa kurang kompak, kurang percaya diri dan tenaganya sudah meningkat. Rasa percaya diri harus ditingkatkan, dalam menari itu tidak ada yang namanya minder. Tugasnya yaitu berlatih dengan kleompoknya masing-masing, karena minggu depan akan dilaksanakan evaluasi akhir.

\section{Pelajaran Seni Tari Kelas VII A Tanggal 5 Maret 2012}

Pembelajran Seni Tari kelas VII A terdiri dari tiga tahapan yaitu pendahuluan, kegiatan inti, dan penutup. Pendahuluan yaitu Ibu Wahyu memberikan apersepsi yaitu siswa berlatih dengan kelompoknya masing-masing selama 15 menit, karena diadakan penilaian.

Kegiatan Inti yaitu siswa berlatih dengan kelompoknya masing-masing selama 15 menit. Ibu Wahyu memanggil kelompok 2 dan 4 untuk menari, sedangkan kelompok 1 dan 3 bermain musik. Kelompok 2 dan 4 menari, dilanjutkan dengan Ibu Wahyu memberikan evaluasi. Ibu Wahyu memanggil perwakian dari kelompok 2 dan 4. Kelompok 2 diwakilkan oleh Dhiya, dan kelompok 4 diwakilkan oleh Eka. Dhiya dan Eka menari besama-sama, tetapi gerakannya berbeda. Dhiya dan Eka selesai, Ibu Wahyu memberika kesemptan kepada siswa untuk memberikan komentar. Kintan memberikan komentarnya yaitu Dhiya kurang percaya diri dan tekniknya kurang, sedangkan Eka percaya diri sudah ada dan tekniknya kurang. Hasil pembelajaran Seni Tari kelas VII A dapt dilihat dari segi kognitif, afektif dan psikomotorik. Kognitif yaitu siswa kurang berinteraksi antar siswa dalam satu kelompok. Afektif yaitu siswa bertanya kepada Ibu Wahyu apabila mengalami kesulitan dalam mengeksplorasi gerak tari. Psikomotorik yaitu siswa mampu memeragakan hasil mengeksplorasi kelompoknya.

Penutup yaitu Ibu Wahyu mengevaluasi pembelajaran hari ini dan memberikan tugas kepada para iswa. Evaluasinya yaitu pelanjaran kali ini lebih baik dari pada pelajaran minggu kemarin dan pengembangkan gerakannya sudah bagus, kompak antara 1 kelompok kurang, dan teknik geraknya diperbaiki. Tugasnya yaitu evaluasi perkelompok jadi haus berlatih di rumah dengan kelompok masing-masing.

\section{Pelajaran Seni Tari Kelas VII D tanggal 6 Marert 2012}

Pembelajaran Seni Tari kelas VII D, terdiri dari pendahuluan, kegiatan inti dan penutup. Pendahuluan yaitu Ibu Wahyu memberikan apersepsi yaitu siswa diberikan waktu 15 menit untuk berlatih dengan kelompoknya masing-masing, karena akan diadakan evaluasi secara kelompok.

Kegiatan Inti yaitu siswa berlatih dengan kelompoknya masing-masing dengan wakttu 1 menit. Siswa selesai berlatih, Ibu Wahyu memanggil kelompok 1 dan 3 menari, 
sedangkan kelompok 2 dan 4 bermain musik. Kelompok 1 dan 3 selesai menmpilkan, dilanjutkan dengan Ibu Wahyu memberikan evaluasi. Ibu Wahyu memanggil perwakila dari kelompok 1 dan 3 utuk menampilkan hasil diskusi kelompok mereka kembali, kelompok 1 diwakilkan oleh Diah dan kelompok 3 oleh Luqi. Diah dan Luqi menar bersama, dengan begerakan yang berbeda. Diah dan Luqi selesai memeraakan, dilanjutkan dengan Ibu Wahyu menyuruh Hudi untuk memberikan komentar dari gerakan Diah dan Luqi. Menurut Hudi gerakan yang diperagakan Diah dan Luqi yaitu Diah dan Luqi kurang serius dalam menarikannya dan teknik menarinya kurang. Hasil pembelajaran Seni Tari kelas VII D dapat dilihat dari kognitif, afektif dan psikomotorik. Kognitif yaitu siswa bisa mengeksplorasi gerak tari. Afektif yaitu siswa terlihat kompak karena semua anggota memperhatikan ada siswa yang sedang mendemonstrasikan gerak. Psikomotorik yaitu siswa memeragakan hasil mengeksplorasi gerak tari.

Penutup yaitu Ibu Wahyu memberikan evaluasi dan tugas kepada siswa. Evaluasinya yaitu semua kelompok terlihat kurang kompak, tekniknya diperbaiki lagi, kerja sama antar siswa didalam kelompok sangat penting dan pola lantai diperbaiki lagi. Tugasnya yaitu Minggu depan evaluasi maju perkelompok dan harus berlatih di rumah dengan kelompok maing-masing.

\section{Pelajaran Seni Tari Kelas VII C tanggal 7 Maret 2012}

Pembeajaran Seni Tari kelas VIII C terdiri dari tiga tahapan yaitu pendahuluan, kegiatan inti dan peenutup. Pendahuluan yaitu Ibu Wahyu memberikan apersepsi yaitu siswa diberikan waktu 15 menit untuk berlatih dengan kelompoknya masing-masing, karena akan diadakan evaluasi.

Kegiatan Inti yaitu siswa berlatih dengan kelompoknya masing-masing selama 15 menit. Siswa selesai berlatih, Ibu Wahyu memanggil kelompok 2 dan 4 untuk menari, dan kelompok 1 ddan 3 bermain musik. Kelompok 2 dan 4 selesai menari, dilanjutkan dengan Ibu Wahyu memberikan evaluasi. Ibu Wahyu menaggil perwakilan dari kelompok 2 dan 4 untuk menampilkan kembali hasil mengeksplorasi gerak tari.

Kelompok 2 diwakilkan sedangkan kelompok 4 diwakilkan Erna dan Karina selesai menari, Ibu Wahyu menunjuka Asih untuk komentarnya. Menurut Asih, gerakan yang ditampilkan Erna dan Kirana sudah terlihat bagus, yang kurang hanya tekniknya. Hasil penelitian Seni Tari kelas VII C terlihat dari segi kognitif, afektif dan psikomotorik. Kognitif adalah siswa bisa mengeksplorasi gerak tari. Afektif yaitu siswa merasa percaya diri saat menampilkan hasil mengeksplorasi kelompoknya masing. Psikomotorik memeragakan hasil mengeksplorasi secara kelompok.

Penutup yaitu memberikan evaluasi dan tugas kepada siswa. Evaluasinya yaitu teknik gerak belum dilakukan dengan sebaik-baiknya, musik dan tariannya tidak bisa dipisahkan satu kesatuan jadi harus kompak, pola lantai silahkan diperbaiki, level 
tinggi rendahnya diperhitungkan, variasi geraknya. Tugasnya yaitu siswa berlatih dengan kelompoknya masing-masing, karena minggu depan penilaian yang terakhir.

Pelajaran Seni Tari Kelas VII F tanggal 8 Maret 2012 Pembelajaran Seni Tari kelas VII F terdiri dari tiga tahap yaitu pendahuluan, kegiatan inti, dan penutup. Pendahuluan yaitu Ibu Wahyu memberikan apersepsi yaitu siswa diberikan waktu 15 menit untuk berlatih dengan kelompoknya masing-masing. Penilaian dilakukan yatu dengan 2 kelompok menari dan 2 kelompok bermain musik. Kegiatan inti yaitu Siswa berlaatih dengan kelompok masing-masing dengan waktu 15 menit. Siswa selesai berlatih dengan kelompoknya masing-masing, Ibu Wahyu memanggil kelompok 1 dan 2 menari, sedangkan kelompok 3 dan 4 bermain musik. Kelompok 1 dan 2 menampilkan hasil diskusi, dilanjutkan dengan Ibu Wahyu memberikan evaluasi. Ibu Wahyu memanggil perwakilan dari kelompok 1 dan 2 untuk menampilkan kembali. Perwakilan kelompok 1 yaitu Adit, sedangkan kelompok 2 yaitu Gusnan. Adit dan Gusnan menari bersama-sama dengan gerakan yang berbeda. Adit dan Gusnan selesai menampilkan, Ibu Wahyu menunjuk salah satu siswa yaitu Dewi untuk memberikan komentar dari gerakan yang diperagakan oleh Adit dan Gusnan.

Menurut Dewi gerakan yang ditampilkan Adit dan Gusnan yaitu gerakan yang ditampilkan Adit dan Gusnan kurang serisus, terus tariannya juga belum hafal. Hasil pembelajaran Seni Tari kelas VII F dapat dilihat dari segi kognitif, afektif, dan psikomotorik. Kognitif yaitu siswa mampu memahami tentang mengeksplorasi gerak tari. Afektif yaitu siswa terlihat kompak saat para siswa berlatih dengan kelompoknya Psikomotorik yaitu siswa memeragakan hasil mengeksplorasi gerak dengan cukup kompak. Penutup yaitu Ibu Wahyu memberikan evaluasi dan tugas kepada siswa. Evaluasinya yaiitu kekompakan, teknik yang benar, percaya diri merupakan sikap yang harus perhatikan untuk pelajaran minggu depan. Tugasnya yaitu minggu depan maju perkelompok, 1 kelompok bermain menari, lainnya bermain musik sebagai nilai akhir kalia, jadi harus berlaatih dengan kelompoknya supay kompak.

\section{Pelajaran Seni Tari Kelas VII B tanggal 8 Maret 2012}

Pembelaajarn Seni Tri kelaas VII B terdiri dari tiga tahap yaitu pendahuluan, kegiatan inti, dan penutup. Pendahuluan yaitu Ibu Wahyu memberikan apersepsi yaitu siswa diberikan waktu 15 menit untuk berlatih dengan kelompoknya msing-masing. Evaluasi dilakukan 2 kelompok menari dan 2 kelompok bermain musik.

Kegiatan Inti yaitu siswa berlatih dengan kelompoknya masing-masing dengan waktu 15 menit. Siswa selesai berlatih dengn kelompoknya, Ibu Wahyu memanggil kelompok 2 dan 3 menari, sedangkan kelompok 1 dan 4 bermain musik. Kelommpo 2 dan 3 selesai menari, Ibu Wahyu memberikan evaluasi. Ibu Wahyu memanggil perwakilan dari 
kelompok 2 dan 3 untuk menari lagi. Perwakilan dari kelompok 2 yaitu Adi dan kelompok 3 yaitu Yovensius. Adi dan Yovensius selesai menari, Ibu Wahyu menawarkan kepada siswa untuk memberikan komentarnya. Siswa bernama Tita berkomentar tentang gerakan yang diperagakan Adi dan Yovensius yaitu penampilan Adi dan Yovensius cukup bagus dari segi hafalan dan pecaya dirinya, tetapi dalam tekniknya Adi dan Yovensius kurang. Hasil pembelajaran Seni Tari kelas VII F terlihat dari segi kognitif, afektif, dan psikomotorik. Kognitif yaitu siswa secara berkelompok mampu memahami tentang cara mengeksplorasi gerak tari. Afektif yaitu siswa terlihat kompak saat memeragakan gerak. Psikomotorik yaitu siswa memeragakan hasil mengeksplorasi gerakan tari dengan rasa percaya diri.

Penutup yaitu Ibu Wahyu memberikan evaluasi dan tugas kepada siswa. Evaluasinya yaitu dalam menari harus percaya diri, harus terlihat kompak dengan cara berlatih dengan kelompoknya masing-masing, teknik dalam menari diperbaiki, dan menarikan sesuai dengan iringannya. Tugasnya yaitu Siswa minggu depaan harus sudah kompak.

\section{Faktor penghambat dalam pembelajaran Seni Tari dengan menggunakan model pembelajaran Interaktif Kelompok di SMP Bina Sejahtera}

Konsentrasi siswa dan sikap siswa terhadap guru saat proses belajar mengajar seni tari sangat berpengaruh terhadap kelancaran proses belajar mengajar, Sikap siswa terhadap guru saat proses pembelajaran kurang menghargai guru dapat mengganggu kelancaran belajar mengajar siswa karena siswa yang tidak menghargai guru akan membuat kegaduhan di dalam, sehingga mengganggu kelancaran belajar mengajar, dan Motivasi siswa terhadap pembelajaran Seni Tari kurang, terutama pada siswa putra, karena ada yang beranggapan menari hanya untuk anak putri, sehingga banyak anak putra yang kurang begitu tertarik terhadap pembelajaran Seni Tari.

Faktor pendukung dalam pembelajaran Seni Tari dengan meggunakan model pembelajaran Interaktif Kelompok di SMP N 5 Magelaang

Pengalaman mengajar guru seni tari yang sudah cukup lama, sehingga Ibu Wahyu dapat dengan mudah mengajarkan siswa pembelajaran Seni Tari, dan Sarana dan prasarana di SMP Bina Sejahtera sudah memadai untuk menunjang keberhasilan kegiatan belajar mengajar. mempersiapkan materi yang akan diajarkan kepada siswa dan media yang akan digunakan, setelah masuk ke kelas Ibu Wahyu memberikan apersepsi atau pree test kepada para siswa. Tahapan kegiatan inti yaitu guru memberikan materi kepada para siswa, dilanjutkan dengan siswa berdiskusi dengan kelompoknya masing-masing dan apabila mengalami kesulitan siswa bertanya kepada guru. Tahap penutup yaitu guru memberikan evaluasi dari hasil pembelajaran dilanjutkan dengan guru memberikan kesimpulan dan tugas kepada para siswa. Materi yang diajarkan Ibu Wahyu setiap kelas sama, tetapi dalam kegaiatan apresiasi setiap kelas menonton video yang berbeda-beda. Kelas A menonton

Jurnal Insitusi Politeknik Ganesha Medan 
video tari Gundul Pacul, kelas B menonton video tari Padang Bulan, kelas C menonton video tari Gundul Pacul, kelas D menonton video Jaranan, kelas E menonton video Gundul Pacul, dan kelas F menonton video Lir Ilir. Hasil pembelajaran Seni Tari di SMP Bina Sejahtera dari kelas A sampai $F$ dilihat dari segi kognitif yaitu siswa mampu mengeksplorasi gerak tari secara kelompok, afektif yaitu siswa merasa percaya diri menari di depan teman- temannya, psikomotorik yaitu siswa mampu memeragakan hasil eksplorasi gerak tari secara kelompok.

Faktor-faktor penghambat dan pendukung model pembelajaran Interaktif Kelompok dalam pelajaran Seni Tari di SMP Bina Sejahtera. Faktor penghambat pembelajaran Interaktif Kelompok dalam pembelajaran Seni Tari di SMP Bina Sejahtera yaitu kurangnya konsentrasi siswa dalam menerima pelajaran, sikap siswa yang kurang menghargai guru dalam proses pembelajaran, kurangnya motivasi siswa terhadap pembelajaran Seni Tari. Faktor Pendukung pembelajaran Interaktif Kelompok dalam pembelajaran Seni Tari di SMP Bina Sejahtera yaitu pengalaman mengajar Ibu Wahyu yang sudah lama, sarana dan prasarana di SMP Bina Sejahtera yang sudah memadai.

\section{CONCLUSIONS}

Berdasarkan hasil penelitian tentang "Model Pembelajaran Interaktif Kelompok Pada Mata Pelajaran Seni Tari Kelas VII SMP Bina Sejahtera", maka peneliti menarik kesimpulan sebagai berikut: Pelaksanaan pembelajaran Seni Tari di SMP Bina Sejahtera kelas A sampai $\mathrm{F}$ dengan menggunakan model pembelajaran Interaktif Kelompok terdiri dari tiga tahapan yaitu pendahuluan, kegiatan inti, dan penutup. Tahapan pendahuluan yaitu Ibu Wahyu

\section{REFERENCES}

Dalyono, M. 2007. Psikologi Pendidikan. Jakarta: Renika Cipta

Dimyati dan Mujiono. 2009. Belajar dan Pembelajaran. Jakarta: Rineka Cipta

Harlen, W.1996. The Teaching of Science. London: David Fulton Publisher Ltd.

Hartono. 2007. "Pengembangan Model Pembelajaran Seni Berbasis Kompetensi Pada Anak Usia Dini”. Harmonia Volume 8 No 12007.

Jazuli, M.1994. Telaah Teoritis Seni Tari. Semarang: IKIP Semarang Press

.2001. Metode Penelitian kualitatif. Semarang: Jurusan Sendratasik Universitas Negeri Semarang.

Jurnal Insitusi Politeknik Ganesha Medan

Juripol, Volume 4 Nomor 1 Maret 2021 
."Model Pembelajaran Tari Pendidikan paa Siswa SD/MI Semarang". Harmonia Volume 10 No 2 Tahun 2010.

Mulyasa, E. 2006. Kurikulum Berbasis Kompetensi. Bandung: PT. Remaja Rosdakarya

Nurhasanah, Reny. 2004. Perbandingan Model Pembelajaran Siklus Berbasis Empiris Induktif dan Model Pembelajaran Interaktif Pada Pembelajaran IPA Fisika. Skripsi Pada FMIPA UNNES: Tidak diterbitkan

Rohidi, Tjetjep Rohendi. 1992. Analisis Data Kualitatif. Jakarta. Universitas Indonesia Sumiyatiningsih, D. 2006. Mengajar dengan Kreatif dan Menarik. Jakarta: Andi

Surakhmad, Winarno. 1980. Pengantar Interaksi Mengajar Dasar dan Teknik Metodologi Pengajaran. Bandung: Transito 